\title{
GAMBARAN PENDONOR DARAH DI UTD PMI KABUPATEN BANTUL TAHUN 2020
}

\author{
Atik Dina Naseha ${ }^{1}$,Nur'Aini Purnamaningsih ${ }^{2}$, Kuswanto Hardjo ${ }^{3}$ \\ Universitas Jenderal Achmad Yani Yogyakarta ${ }^{123}$ \\ e-mail: 1dinanaseha14@gmail.com, ${ }^{2}$ nurainipurnamaningsih21@gmail.com, \\ ${ }^{3}$ kuswanto.hardjo@gmail.com
}

\begin{abstract}
At the end of 2019, it was found that there was a very fast mutating virus called the Covid-19 virus, this virus causes diseases ranging from coughs to colds to death, efforts to prevent the spread of this virus by limiting the social scale of the community which causes a decrease in the number of blood donors which has an impact on the amount of blood stock in Blood Donation Unit. The objective of this study was to determine the description of blood donors based on blood type, gender, age, and type of donor at Blood Donation Unit Bantul Regency in 2020. This study was an activity report by observing secondary data obtained from Blood Donation Unit Bantul Regency. The number of donors was 8.212 donors, of which the number of donations from inside the building was 5.936 donors (72,28\%), and the number of donations from mobile units was 2.276 donors $(27,72 \%)$. The results showed that the majority of blood donors were blood group 0, which was 3.506 (42,69\%), and the least blood type was $A B$, which was 468 (5.70\%). The majority of the gender of the donor was male, namely 7.020 (85,48\%), for female, 1.192 (14,52\%). The majority of donors are aged 17-24 years, namely 1.738 (21,16\%), and at least 65 years old $45(0,55 \%)$. The majority of voluntary donors were 5.151 (62,73\%), and the subtitutel family donors were 1.034 (12,59\%). There were 8.212 blood donors where the majority of blood group 0 was 3.506 (42,69\%), male sex was 7.020 (85,48\%), in the 17-24 year age group $1.738(21,16 \%)$, and repeated voluntary donors were $5.151(62,73 \%)$.
\end{abstract}

Keywords: blood donor; characteristics; blood donation unit.

\begin{abstract}
ABSTRAK
Akhir tahun 2019 ditemukan adanya virus yang cepat sekali bermutasi yang disebut virus Covid-19, virus ini menyebabkan penyakit dari mulai batuk pilek hingga kematian, upaya pencegahan penyebaran virus ini dengan pembatasan skala sosial masyarakat yang menyebabkan menurunnya jumlah pendonor darah yang berdampak pada jumlah stok darah yang dimiliki UTD. Penelitian ini bertujuan untuk mengetahui gambaran pendonor darah berdasarkan golongan darah, jenis kelamin, usia, dan jenis pendonor di UTD PMI Kabupaten Bantul tahun 2020. Penelitian ini merupakan laporan kegiatan dengan cara observasi terhadap data sekunder yang diperoleh dari UTD PMI Kabupaten Bantul. jumlah pendonor sebanyak 8.212 pendonor, dimana jumlah donasi yang berasal dari dalam gedung sebanyak 5.936 pendonor $(72,28 \%)$, dan jumlah donasi yang berasal dari mobile unit sebanyak 2.276 pendonor $(27,72 \%)$. Hasil penelitian menunjukkan bahwa mayoritas pendonor darah golongan darah 0 yaitu $3.506(42,69 \%)$, dan paling sedikit golongan darah AB yaitu $468(5,70 \%)$. Mayoritas jenis kelamin pendonor adalah laki-laki yaitu $7.020(85,48 \%)$, untuk perempuan $1.192(14,52 \%)$. Mayoritas pendonor usia 17-24 tahun yaitu $1.738(21,16 \%)$, dan paling sedikit usia $\geq 65$ tahun $45(0,55 \%)$. Mayoritas jenis pendonor sukarela berulang $5.151(62,73 \%)$, dan paling sedikit pendonor pengganti $1.034(12,59 \%)$. Didapatkan pendonor darah sebanyak 8.212 pendonor di mana mayoritas golongan darah 0 yaitu $3.506(42,69 \%)$, berjenis kelamin laki-laki yaitu 7.020 $(85,48 \%)$, pada kelompok usia 17-24 tahun yaitu $1.738(21,16 \%)$, dan pendonor sukarela berulang yaitu 5.151 $(62,73 \%)$.
\end{abstract}

Kata Kunci: pendonor darah; karakteristik; unit donor darah. 

Vol. 16 No. 3 September - Desember 2021

\section{PENDAHULUAN}

\section{Latar Belakang}

Pelayanan darah merupakan salah satu upaya kesehatan dalam rangka penyembuhan dan pemulihan, kegiatan pelayanan darah yang dilakukan oleh Unit Transfusi Darah (UTD) meliputi kegiatan perencanaan, pelestarian pendonor darah, pendistribusian darah, dan tindakan medis pemberian darah kepada pasien ${ }^{(1)}$.

Pertumbuhan penduduk, angka harapan hidup yang tinggi, diagnosis penyakit, hematologi, bedah, transplantasi, dan pengobatan pasien merupakan tantangan yang berkelanjutan untuk bank darah rumah sakit dalam menyediakan stok darah yang tercukupi. Selanjutnya bank darah rumah sakit mengajukan permintaan stok darah ke Unit Transfusi Darah (UTD) sebagai penyedia darah untuk memenuhi stok di bank darah rumah sakit. World Health Organization (WHO) menjelaskan bahwa tidak tersedianya darah telah menyebabkan kematian dan banyak pasien yang menderita gangguan kesehatan ${ }^{(2)}$.

Berdasarkan data dari Badan Pusat Statistik Daerah Istimewa Yogyakarta, jumlah penduduk Kabupaten Bantul tahun 2020 berjumlah 985.770 jiwa. Menurut WHO kebutuhan darah adalah $2 \%$ dari jumlah penduduk sehingga dapat dihitung perkiraan kebutuhan darah di Kabupaten Bantul sebanyak 19.715 kantong (3).

Akhir tahun 2019 ditemukan adanya virus yang cepat sekali bermutasi yang dapat menyebabkan penyakit dari mulai batuk pilek dan penyakit lain bahkan sampai kematian. Menurut data yang dilansir WHO pada tanggal 31 Desember 2019 WHO kantor negara Tiongkok menerima kabar kasus Pneumonia yang penyebabnya belum diketahui. Kasus ini terjadi di Kota Wuhan Provinsi Hubei, Tiongkok. Oleh pemerintah Tiongkok, pada tanggal 7 Januari 2020 suatu Coronavirus baru (Covid-19) berhasil diisolasi dan diidentifikasi sebagai virus penyebabnya ${ }^{(4)}$.

Salah satu upaya untuk mencegah penyebaran virus ini yaitu dengan diberlakukan PSBB atau pembatasan sosial berskala besar dengan menutup sekolah, perguruan tinggi, dan tempat-tempat umum lainnya yang beradampak terhadap beberapa bidang termasuk bidang kesehatan. Hal ini merupakan salah satu penyebab yang paling berpengaruh terkait jumlah pendonor di Unit Transfusi Darah ${ }^{(5)}$.

Berdasarkan data jumlah permintaan darah dan darah yang dapat dipenuhi oleh UTD PMI Kabupaten Bantul pada tahun 2019 dan tahun 2020 terdapat perbedaan yang cukup signifikan, pada bulan Maret tahun 2019 permintaan darah ke UTD PMI Bantul yaitu 451 kantong dan yang dapat terpenuhi yaitu 440 kantong, selisih 11 kantong dari permintaan darah, sedangkan pada bulan Maret tahun 2020 permintaan darah ke UTD Bantul yaitu 265 kantong dan yang dapat terpenuhi yaitu 216 kantong, selisih 49 kantong. Hal ini menunjukkan bahwa pandemi Covid19 berpengaruh terhadap stok darah yang dimiliki oleh UTD PMI Kabupaten Bantul.

Tujuan dari penelitian ini adalah untuk mengetahui gambaran pendonor darah berdasarkan karkteristik golongan darah, jenis kelamin, usia, dan jenis pedonor darah di UTD PMI Kabupaten Bantul tahun 2020.

\section{METODE}

Penelitian ini merupakan laporan kegiatan dengan cara observasi terhadap data sekunder dari UTD PMI Kabupaten Bantul tahun 2020 yang mencakup data karakteristik golongan darah, jenis kelamin, usia, dan jenis pendonor darah.

Penelitian ini dilakukan di UTD PMI Kabupten Bantul yang beralamat di Jalan Jenderal Sudirmaan Nomor 1 Bantul, Kabupaten Bantul, Daerah Istimewa Yogyakarta. Penelitian ini dilakukan pada bulan Maret sampai Mei tahun 2021.

Variabel dalam penelitin ini yaitu mencakup karakteristik pendonor darah yaitu golongan darah, jenis kelamin, usia, dan jenis pendonor darah di UTD PMI Kabupaten Bantul tahun 2020. Alat pengumpulan data dalam penelitian yang digunakan yaitu data excell dari buku tahunan pendonor dari UTD PMI Kabupaten Bantul. Metode pengumpulan data dalam penelitian yaitu obsrevasi. Data observasi terhadap rekapan buku catatan tahunan donor darah di UTD PMI Kabupaten Bantul pada tahun 2020 .

\section{HASIL}

Berdasarkan data yang diperoleh dari UTD PMI Kabupaten Bantul pada bulan Januari sampai dengan bulan Desember 2020 didapatkan jumlah pendonor sebanyak 8.212 pendonor, dimana jumlah donasi yang berasal dari dalam gedung sebanyak 5.936 pendonor $(72,28 \%)$, dan jumlah donasi yang berasal dari mobile unit sebanyak 2.276 pendonor $(27,72 \%)$.

\section{Karakteristik Pendonor Darah Berdasarkan Golongan Darah}

Pengukuran untuk kategori golongan darah dibagi menjadi golongan darah $\mathrm{A}$, golongan darah $\mathrm{B}$, golongan darah $\mathrm{AB}$, dan golongan darah 0. Gambaran karakteristik pendonor berdasarkan golongan darah dapat dilihat pada Tabel 1.

Tabel 1. Karakteristik Pendonor Darah Berdasarkan Golongan Darah

$\begin{array}{ccc}\begin{array}{c}\text { Golongan } \\ \text { Darah }\end{array} & \text { Jumlah } & \text { Persentase }\end{array}$




\begin{tabular}{crr}
\hline A & 1.989 & 24,22 \\
\hline B & 2.249 & 27,39 \\
\hline AB & 468 & 5,70 \\
\hline 0 & 3.506 & 42,69 \\
\hline Jumlah & 8.212 & 100,00 \\
\hline
\end{tabular}

Pada Tabel 1 didapatkan karakteristik pendonor darah berdasarkan golongan darah AB0 mayoritas pendonor darah adalah golongan darah 0 sebanyak $3.506(42,69 \%)$, dan jumlah pendonor paling sedikit yaitu pendonor dengan golongan darah $\mathrm{AB}$ yaitu sebanyak $468(5,70 \%)$ dari total 8.212 pendonor darah.

\section{Karakteristik Pendonor Darah Berdasarkan Jenis} Kelamin

Pengukuran jumlah pendonor darah di UTD PMI Kabupaten Bantul tahun 2020 berdasarkan karakteristik jenis kelamin adalah laki-laki dan perempuan. Gambaran karakteristik pendonor berdasarkan jenis kelamin dapat dilihat pada Tabel 4.2.

Tabel 2. Karakteristik Pendonor Darah Berdasarkan Jenis Kelamin

\begin{tabular}{ccr}
\hline Jenis Kelamin & Jumlah & Persentase \\
\hline Laki-laki & 7.020 & 85,48 \\
\hline Perempuan & 1.192 & 14,52 \\
\hline Jumlah & 8.212 & 100,00 \\
\hline
\end{tabular}

Pada Tabel 2 didapatkan karakteristik pendonor darah berdasarkan jenis kelamin mayoritas pendonor darah adalah laki-laki dengan jumlah 7.020 $(85,48 \%)$ dari total 8.212 pendonor darah.

\section{Karakteristik Pendonor Darah Berdasarkan Usia}

Pengukuran jumlah pendonor darah berdasarkan di UTD PMI Kabupaten Bantul tahun 2020 berdasarkan karakteristik usia yaitu kategori usia 17-24 tahun, 25-44 tahun, 45-64 tahun, dan $\geq 65$ tahun. Gambaran karakteristik pendonor berdasarkan usia dapat dilihat pada Tabel 3.

Tabel 3. Karakteristik Pendonor Darah Berdasarkan Usia

\begin{tabular}{ccc}
\hline Usia & Jumlah & Persentase \\
\hline 17-24 tahun & 1.738 & $21,16 \%$ \\
\hline 25-44 tahun & 4.181 & $58,59 \%$ \\
\hline
\end{tabular}

\begin{tabular}{ccc}
\hline 45-64 tahun & 1.618 & $19,70 \%$ \\
\hline$\geq 65$ tahun & 45 & $0,55 \%$ \\
\hline Jumlah & 8.212 & $100 \%$ \\
\hline
\end{tabular}

Pada Tabel 3 didapatkan karakteristik pendonor darah berdasarkan usia terdapat perbedaan lebar interval 17-24 $=8$ dengan $25-44=20$, sehingga untuk melihat frekuensi yang lebih tinggi maka jumlah pendonor dibagi dengan lebar interval, menjadi 1.738/8 $=217,25$ dan 4181/20 $=209,05$, sehingga frekuensi yang lebih tinggi ada pada kelompok 17-24 tahun.

\section{Karakteristik Pendonor Darah Berdasarkan Jenis Pendonor Darah}

Pengukuran jumlah pendonor darah di UTD PMI Kabupaten Bantul tahun 2020 berdasarkan karakteristik jenis pendonor darah adalah sukarela baru, sukarela berulang, dan pengganti. Gambaran karakteristik pendonor berdasarkan jenis pendonor darah dapat dilihat pada Tabel 4.

\begin{tabular}{ccc}
\multicolumn{3}{c}{$\begin{array}{c}\text { Tabel 4. Karakteristik Pendonor Darah } \\
\text { Berdasarkan Jenis Pendonor Darah }\end{array}$} \\
\hline $\begin{array}{c}\text { Jenis Pendonor } \\
\text { Darah }\end{array}$ & Jumlah & Persentase \\
\hline Sukarela Baru & 2.027 & $24,68 \%$ \\
\hline $\begin{array}{c}\text { Sukarela } \\
\text { Berulang }\end{array}$ & 5.151 & $62,73 \%$ \\
\hline Pengganti & 1.034 & $12,59 \%$ \\
\hline Jumlah & 8.212 & $100 \%$
\end{tabular}

Pada Tabel 4 didapatkan didapatkan jumlah pendonor darah di UTD PMI Kabupaten Bantul tahun 2020 berdasarkan jenis pendonor darah mayoritas adalah pendonor sukarela berulang yaitu sebanyak $5.151(62,73 \%)$.

\section{PEMBAHASAN}

\section{Karakteristik Pendonor Darah Berdasarkan Golongan Darah}

Jumlah pendonor darah di UTD PMI Kabupaten Bantul pada tahun 2020 yaitu sebayak 8.212 pendonor. Golongan darah 0 merupakan golongan darah yang memiliki jumlah pendonor paling banyak yaitu sebanyak 3.506 pendonor $(42,69 \%)$, kemudian golongan darah B dengan jumlah pendonor sebanyak 2.249 pendonor $(27,39 \%)$, selanjutnya golongan darah A dengan jumlah pendonor sebanyak 

Vol. 16 No. 3 September - Desember 2021

1.989 pendonor $(24,22 \%)$, dan jumlah paling sedikit yaitu golongan darah $\mathrm{AB}$ dengan jumlah pendonor sebanyak 468 pendonor $(5,70 \%)$ dari total 8.212 pendonor.

Berdasarkan penelitian yang dilakukan oleh Putri (2019) didapatkan mayoritas pendonor darah yaitu golongan darah 0 dengan persentase $37,33 \%$, selanjutnya golongan darah B dengan persentase $30,16 \%$, kemudian golongan darah A dengan persentase $24,78 \%$, dan jumlah pendonor paling sedikit yaitu golongan darah $\mathrm{AB}$ dengan persentase $7,73 \%$. Hal ini menunjukkan kesesuaian dengan penelitian yang dilakukan yaitu mayoritas pedonor darah yaitu golongan darah 0 sedangkan yang paling sedikit yaitu golongan darah $\mathrm{AB}^{(6)}$.

Berdasarkan data dari Pusat Data dan Informasi Kementerian Kesehatan Republik Indonesia, distribusi donasi darah tahun 2016 menurut golongan darah menyatakan bahwa golongan darah 0 merupakan golongan darah paling banyak yaitu 39\%, selanjutnya golongan darah B yaitu $28 \%$, kemudian golongan darah A yaitu 24\%, dan jumlah paling sedikit yaitu golongan darah $\mathrm{AB}$ yaitu $8 \%{ }^{(7)}$.

Berdasarkan data Statistik Kependudukan Daerah Istimewa Yogyakarta tahun 2020, penduduk di Kabupaten Bantul dengan golongan darah 0 merupakan golongan darah paling banyak yaitu $15 \%$, kemudian golongan darah B yaitu $11 \%$, selanjutnya golongan darah A yaitu $8 \%$, urutan paling sedikit yaitu golongan darah $\mathrm{AB}$ yaitu 3,3\%, dan untuk sisanya tidak diketahui golongan darahnya yaitu sebanyak $62,7 \%{ }^{(3)}$.

Hal ini menunjukkan kesesuaian dari hasil penelitian dengan data jumlah populasi penduduk kabupaten Bantul berdasarkan golongan darah yaitu jumlah golongan darah terbanyak yaitu golongan darah 0 , kemudian golongan darah $\mathrm{B}$, selanjutnya golongan darah A, dan jumlah yang paling sedikit yaitu golongan darah AB.

\section{Karakteristik Pendonor Darah Berdasarkan Jenis Kelamin}

Hasil penelitian menunjukkan bahwa sebagian besar pendonor darah di UTD PMI Kabupaten Bantul berjenis kelamin laki-laki yaitu sebanyak 7.020 pendonor $(85,48 \%)$, sedangkan pendonor berjenis kelamin perempuan lebih sedikit yaitu sebanyak 1.192 pendonor $(14,52 \%)$ dari total 8.212 pendonor darah.

Berdasarkan penelitian Alvira dan Danarsih (2016), pendonor laki-laki lebih mendominasi daripada pendonor yang berjenis kelamin perempuan ${ }^{(8)}$. Penelitian yang dilakukan oleh Purnamaningsih, Supadmita, dan Danarsih (2020) menunjukkan bahwa pendonor darah berjenis kelamin laki-laki memiliki presentase yang lebih tinggi daripada pendonor perempuan $^{(9)}$. Hal ini menunjukkan kesesuaian dengan penelitian yang dilakukan yaitu pendonor berjenis kelamin laki-laki lebih mendominasi daripada pendonor berjenis kelamin perempuan.
Berdasarkan data dari Pusat Data dan Informasi Kementerian Kesehatan Republik Indonesia distribusi donasi darah menurut jenis kelamin tahun 2016 menyatakan bahwa pendonor paling banyak yaitu berjenis kelamin laki-laki dengan persentase $72,5 \%$ dan untuk pendonor berjenis kelamin perempuan dengan persentase $27,5 \%{ }^{(7)}$.

Berdasarkan data Statistik Kependudukan Daerah Istimewa Yogyakarta tahun 2020, penduduk Kabupaten Bantul lebih banyak berjenis kelamin perempuan yaitu $50,15 \%$, dan untuk penduduk berjenis kelamin laki-laki yaitu 49,8\%(3). Hal ini menunjukkan ketidaksesuaian dengan hasil penelitian yang telah dilakukan yang menunjukkan donor dengan jenis kelamin laki-laki lebih banyak daripada donor berjenis kelamin perempuan.

Hal ini dikarenakan syarat donor untuk perempuan lebih banyak daripada laki-laki, misalnya perempuan yang sedang menstruasi, hamil, dan menyusui tidak boleh mendonorkan darahnya. Ratarata frekuensi donor darah perempuan lebih banyak daripada laki-laki, perempuan dapat rutin mendonorkan darahnya seperti laki-laki bila menjaga pola hidupnya dengan menjaga nutrisi yang cukup mengandung zat besi, maka ia dapat lulus saat seleksi sebelum mendonorkan darahnya selama keadaan tubuhnya memadai ${ }^{(8)}$. Hal ini merupakan salah satu faktor ketidaksesuaian antara hasil penelitian yang telah dilakukan yaitu jumlah pendonor laki-laki lebih banyak daripada perempuan dengan jumlah penduduk di Kabupaten Bantul yang lebih banyak perempuan daripada laki-laki dengan adanya lebih banyak syarat donor untuk perempuan.

\section{Karakteristik Pendonor Darah Berdasarkan Usia \\ Hasil penelitian menunjukkan bahwa} sebagian besar pendonor darah berada pada kategori usia dewasa awal yaitu usia 25-44 tahun sebanyak 4.811 pendonor $(58,59 \%)$, kemudian kategori usia remaja yaitu usia 17-24 tahun sebanyak 1.738 pendonor $(21,16 \%)$, selanjutnya kategori usia dewasa akhir yaitu usia 45-64 tahun sebanyak 1618 pendonor $(19,70 \%)$, dan untuk jumlah pendonor paling sedikit pada kategori lansia yaitu usia $\geq 65$ tahun sebanyak 45 pendonor $(0,55 \%)$ dari total 8.212 pendonor.

Berdasarkan penelitian yang dilakukan oleh Putri (2019) didapatkan mayoritas pendonor darah berusia 25-44 tahun dengan persentase 46,20\%, selanjutnya usia 18-24 tahun dengan persentase $28,92 \%$, kemudian usia 45-64 tahun dengan persentase $22,12 \%$, dan untuk jumlah pendonor paling sedikit yaitu usia $\geq 64$ tahun dengan persentase $2,08 \%$. Hal ini menujukkan kesesuaian dengan hasil penelitian yang sudah dilakukan yaitu mayoritas pendonor berusia 25 44 tahun dan pendonor paling sedikit dengan usia $\geq 65$ tahun.

Variasi jumlah pendonor dipengaruhi oleh beberapa faktor, untuk jumlah pendonor paling banyak berada dalam katgeori remaja hal ini dikarenakan 
syarat untuk donor darah adalah 17 tahun sehingga bagi mereka yang berumur 18-24 tahun baru mulai mendonorkan darahnya dan belum merasakan efek donor darah rutin, sedangkan pada kategori usia dewasa dan usia tua sudah memenuhi syarat donor darah dan sudah merasakan efek mendonorkan darah secara rutin $^{(8)}$.

Kemungkinan penyebab jumlah pendonor darah dengan kategori lansia paling sedikit, dikarenakan pada usia ini jika mendonorkan darah untuk pertama kali organ tubuh orang tersebut belum terbiasa beradaptasi untuk membentuk sel darah baru seperti halnya yang rutin mendonorkan darahnya pada kategori usia lansia, adapun bagi pendonor rutin dengan kategori usia lansia organ tubuh pendonor rutin telah terbiasa menyesuaikan diri untuk segera membentuk sel darah baru setelah mendonorkan darahnya, pada kategori usia lansia organ tubuh masih berfungsi secara maksimal untuk pembentukan sel darah yang baru ${ }^{(10)}$. Hal ini menyebabkan pendonor dengan kategori usia dewasa awal memiliki jumlah pendonor lebih banyak daripada kategori umur pendonor lainnya.

\section{Karakteristik Pendonor Darah Berdasarkan Jenis Pendonor Darah}

Hasil penelitian menunjukkan bahwa kebanyakan pendonor darah di UTD PMI Kabupaten Bantul yaitu pendonor darah sukarela berulang yaitu 5.151 pendonor $(62,73 \%)$, kemudian pendonor sukarela baru yaitu 2.027 (24,68\%), selanjutnya untuk jumlah pendonor paling sedikit yaitu pendonor pengganti yaitu 1.034 pendonor $(12,59 \%)$ dari total 8.212 pendonor.

Menurut data Kemenkes RI tahun 2018, pendonor darah berdasarkan jenis pendonor darah dibagi menjadi pendonor darah sukarela dan pendonor darah pengganti. Jumlah pendonor sukarela lebih banyak daripada pendonor pengganti yaitu sebanyak $91,80 \%$, sedangkan pendonor pengganti jumlahnya lebih sedikit dibandingkan dengan pendonor sukarela yaitu sejumlah $8,2 \%$. Hal ini sesuai dengan data yang didapatkan dari hasil penelitian yaitu jumlah pendonor sukarela lebih banyak daripada jumlah pendonor pengganti $^{(7)}$.

\section{KESIMPULAN}

Berdasarkan hasil penelitian yang diperoleh, maka kesimpulan yang dapat diambil yaitu karakteristik pendonor darah di UTD PMI Kabupaten Bantul tahun 2020 berdasarkan golongan darah mayoritas pendonor darah golongan darah 0 sebanyak 3.506 pendonor $(42,69 \%)$, dan untuk jumlah paling sedikit yaitu golongan darah $\mathrm{AB}$ dengan jumlah 468 pendonor $(5,70 \%)$. Berdasarkan jenis kelamin mayoritas pendonor berjenis kelamin laki-laki sebanyak 7.020 pendonor $(85,48 \%)$. Berdasarkan usia mayoritas pendonor berusia 17-24 tahun sebanyak 1.738 pendonor $(21,16 \%)$, dan untuk jumlah pendonor paling sedikit yaitu usia $\geq 65$ tahun sebanyak 45 pendonor $(0,55 \%)$. Berdasarkan jenis pendonor mayoritas adalah pendonor sukarela berulang yaitu sebanyak 5.151 pendonor $(62,73 \%)$, dan untuk jumlah paling sedikit yaitu pendonor pengganti sebanyak 1.034 pendonor $(12,59 \%)$.

\section{DAFTAR PUSTAKA}

1. Peraturan Pemerintah Republik Indonesia Nomor 7 tahun 2011 tentang Pelayanan Darah. (2011). Retrieved January 11, 2021, fromhttps://persi.or.id/wpcontent/uploads/2020/11/pmk722015.pdf

2. World Health Organization. 2016. Global Status Report On Blood Safety And Availability. 2016.https://apps.who.int/iris/bitstream/handle/1 0665/254987/9789241565431-

3. Berita Resmi Statistik. Hasil Sensus Penduduk 2020. (2020). Berita Resmi Statistik No. 08/01/34/Th.XXIII, 21 Januari 2021.

4. World Health Organization. 2020. Pencegahan dan Pengendalian Infeksi (PPI) untuk Novel Coronavirus (COVID-19). Modul 2: Novel coronavirus (COVID-19) Epidemiologi, faktor risiko, definisi dan simptomologi. Translated into Indonesian by Tjioe Lukas Nugroho, from *Infection Prevention and Control (IPC) for Novel Coronavirus (COVID-19), 2020. WHO IPC Technical and Clinical Unit

5. Ou-Yang, J., Shi-Jie, L., Chun-hua, B., Bo He., Jin-yan, C., Hua-qin, L., Yong-shui, F., (2020). Blood donor recruitment in Guangzhou China during the 2019 novel coronavirus (COVID-19) epidemic. Blood donors and blood collection DOI: 10.1111/TRF.15971.

6. Putri, A.S.D. (2019). Produksi Darah dan Karakteristik Pendonor Darah Berdasarkan Golongan Darah ABO dan Rhesus di UTD PMI Kota Yogyakarta Tahun 2019. Yogyakarta: Universitas Jenderal Achmad Yani Yogyakarta.

7. Pusat Data dan Informasi Kementerian Kesehatan Rakyat Indonesia, 2018, 2242- 7659.

8. Alvira, N., \& Danarsih, D. E. (2016). Frekuensi Donor Darah Dapat Mengendalikan Faktor Resiko Penyakit Kardiovaskuler di Unit Donor Darah PMI Kabupaten Bantul. Jurnal Formil Kesmas Respati, 1(1). formilkesmas.respati.ac.id

9. Purnamaningsih, N.A, Supadmi, FRS., Danarsih, D.E. (2020). Gambaran Karakteristik Pendonor Darah di Unit Transfusi Darah (UTD) PMI 
Jurnal Ilmiah Pannmed (Pharmacyst, Analyst, Nurse, Nutrition, Midwivery, Environment, Dental Hygiene)

Vol. 16 No. 3 September - Desember 2021

Kabupaten Bantul Yogyakarta. Semarang:

Prosiding Seminar Nasional Kesehatan 2020.

10. Rachman, F.S., \& Aditya, R. N. (2013). Question and Answers Donor Darah (Pertama). PT Elex Media Komputindo. https://doi.org/170130716 